
치료

서울대학교 의과대학 ${ }^{1}$ 핵의학교실, ${ }^{2}$ 암연구소

강건욱 ${ }^{1,2}$

\title{
Functional Imaging and Peptide Receptor Radionuclide Therapy for Pancreatic Neuroendocrine Tumor
}

\author{
Keon Wook Kang ${ }^{1,2}$ \\ ${ }^{1}$ Department of Nuclear Medicine, ${ }^{2}$ Cancer Research Institute, Seoul National University College of Medicine, Seoul, Korea
}

\begin{abstract}
Somatostatin receptors (SSTR) are overexpressed in various tumors including neuroendocrine tumors. In-111 Octreoscan or Ga-68 DOTATOC positron emission tomography/computed tomography (PET/CT) showed these SSTR expressing tumors in whole body of patients. Ga-68 DOTATOC PET/CT has a better sensitivity and resolution than In-111 Octreoscan with single photon emission computed tomography (SPECT)/CT.. The indications of Ga-68 DOTATOC PET/CT are 1) staging: detect sites of primary and metastasis, 2) re-staging: follow-up of patients with known disease to detect residual, recurrent or progressive disease, 3) prognosis \& management decisions: determine SSTR status \& select patients with SSTR radionuclide therapy, and 4) monitor the response to therapy. Nuclear medicine treatments for neuroendocrine tumors with radioisotope labeling on the somatostatin receptor targeting peptide (peptide receptor radionuclide therapy, PRRT) were conducted in Europe, Australia, and other countries for over 20 years. Eligible patients to be effective to PRRT using Lu-177 DOTATATE can be pre-screened by confirming the expression of somatostatin receptor on tumors using Octreoscan or Ga-68 DOTATOC PET/CT prior to treatment. This pair of molecular targeted treatment and companion diagnostics, so called molecular theranostics makes PRRT a good example for a precision medicine. A multinational clinical trial with the Lu-177 DOTATATE treatment (Lutathera) showed a significant progression free survival over the control group and Ministry of Food and Drug Safety in Korea approved Lutathera. Some doctors are treating patients who are refractory to Lu-177 using Ac-225, an alpha-emitter therapy in Germany and India. The high therapeutic effect of the alpha emitting radionuclides will lead the future of nuclear medicine therapy.
\end{abstract}

Korean J Pancreas Biliary Tract 2021;26(1):10-14

Keywords: Radiation therapy, Neuroendocrine tumors, Precision medicine, Receptors, somatostatin, Radionuclide imaging
Received Nov. 28, 2020

Revised Jan. 15, 2021

Accepted Jan. 16, 2021

Corresponding author : Keon Wook Kang

Department of Nuclear Medicine, Cancer Research Institute, Seoul National University College of Medicine, 101 Daehak-ro, Jongno-gu, Seoul 03080, Korea

Tel: +82-2-2072-2803 Fax: +82-2-745-7690

E-mail; kangkw@snu.ac.kr

ORCID: https://orcid.org/0000-0003-2622-9017

This is an Open Access article distributed under the terms of the Creative Commons Attribution Non-Commercial License (http:// creativecommons.org/licenses/by-nc/3.0/) which permits unrestricted non-commercial use, distribution, and reproduction in any medium, provided the original work is properly cited.

Copyright $\odot 2021$ by The Korean Journal of Pancreas and Biliary Tract 


\section{서 론}

신경내분비종양 환자를 대상으로 소마토스타틴 수용체 표적 펩티드에 방사성동위원소를 표지하여 시행하는 핵의학 치료는 유럽, 호주 등지에서 10여 년 전부터 시행되었다. 옥트레오스캔 (octreoscan) 또는 Ga-68 DOTATOC positron emission tomography (PET) 등 소마토스타틴 수용체 표적 기능 영상은 소마토스타틴 발현을 치료 전에 확인함으로써 효과가 있을 환자를 사전 선별할 수 있고 표적능이 뛰어나 다른 항암치료에 비해 부작용이 적고 치료 효과가 좋다. 그러나 DOTATOC, DOTATATE 등 표적 물질이 특허가 없고 신경내분비종양이 희귀하여 제약회사의 관심이 없어 임상시험이 이루어지지 않아 신약허가를 받지 못하여 동정적 치료가 가능한 일부 국가에서만 시행되었다. 우리나라는 한동안 환자를 독일, 말레이시아 등 외국으로 보내 치료를 하였다. 프랑스의 Advanced Accelerator Applications (AAA) 회사에서 Lu-177 DOTATATE 치료제(Lutathera)로 다국적 임상시험을 하였고 유럽, 미국에서 신약으로 등재되었다. 우리나라에서는 저자와 신경내분비종양 환우회의 노력으로 2019 년 10 월 한국희귀·필수의약품센터를 통해 치료를 시작하였고 2020년 7월 식품의약품안전처에서 품목허가를 하였다. 이제 기능적 핵의학 진단과 치료가 국내에서 가능해져 리뷰를 하고자 한다.

\section{본론}

\section{1. 기능 영상}

췌장 등에서 발생하는 신경 내분비종양은 인슐린종, 글루카곤종, 가스트린종 등 기능성이든 비기능성이든 관계없이 대부분 소마토스타틴 수용체를 발현한다. 내인성 소마토스타틴은 혈중에서 안정적이지 않기 때문에 여러 종류의 소마토스타틴 억제제들이 개발되었는데, 옥트레오타이드 (octreotide), 란레오타이드(lanreotide) 등이 있다. 소마토스타틴과 구조가 유사한 합성 단백약물인 옥트레오타이드에 방사성동위원소를 표지하여 환자에 주사하면 신경내분비종양에 선택적으로 섭취되어 기능적 핵의학영상이 가능하다. 대표적인 예로 ${ }^{111} \mathrm{In}$-옥트레오타이드를 이용한 옥트레오스캔이 있는데 감마카메라를 이용한 전신스캔으로 진단한다(Fig. 1). 이전 연구 결과를 살펴보면
옥트레오스캔은 computed tomography (CT), magnetic resonance imaging (MRI)보다 우수하여 48명 환자의 83개 병변 중 72 개( $87 \%)$ 를 찾은 반면 CT는 33개(44\%), MRI는 29개 (43\%)를 찾았다. ${ }^{1}$ Single photon emission computed tomography (SPECT)/CT를 이용하면 더욱 정확한 진단을 할 수 있다. 49명의 환자에서 스캔, SPECT, SPECT/CT를 비교한 연구를 보면 SPECT/CT가 89 개의 섭취 부위 중 25 개( $28 \%)$ 의 병변을 더욱 정확히 분별할 수 있어 추가적인 병소를 찾거나 염증을 구별하고 생리학적 정상 섭취를 구별할 수 있었다. ${ }^{2}$

최근 옥트레오타이드 유사체를 이용한 PET용 방사성 의약품이 개발되었다. 양전자를 방출하는 $\mathrm{Ga}-68$ 을 표지한 DOTATOC, DOTATATE, DOTANOC인데 이 중 국내에서는 Ga-68 DOTATOC PET/CT가 가능하다. Ga-68 DOTATOC PET/CT를 In-111 옥트레오타이드 SPECT와 비교한 전향적 연구에 의하면 27 명의 신경내분비종양 환자에서 PET/CT는

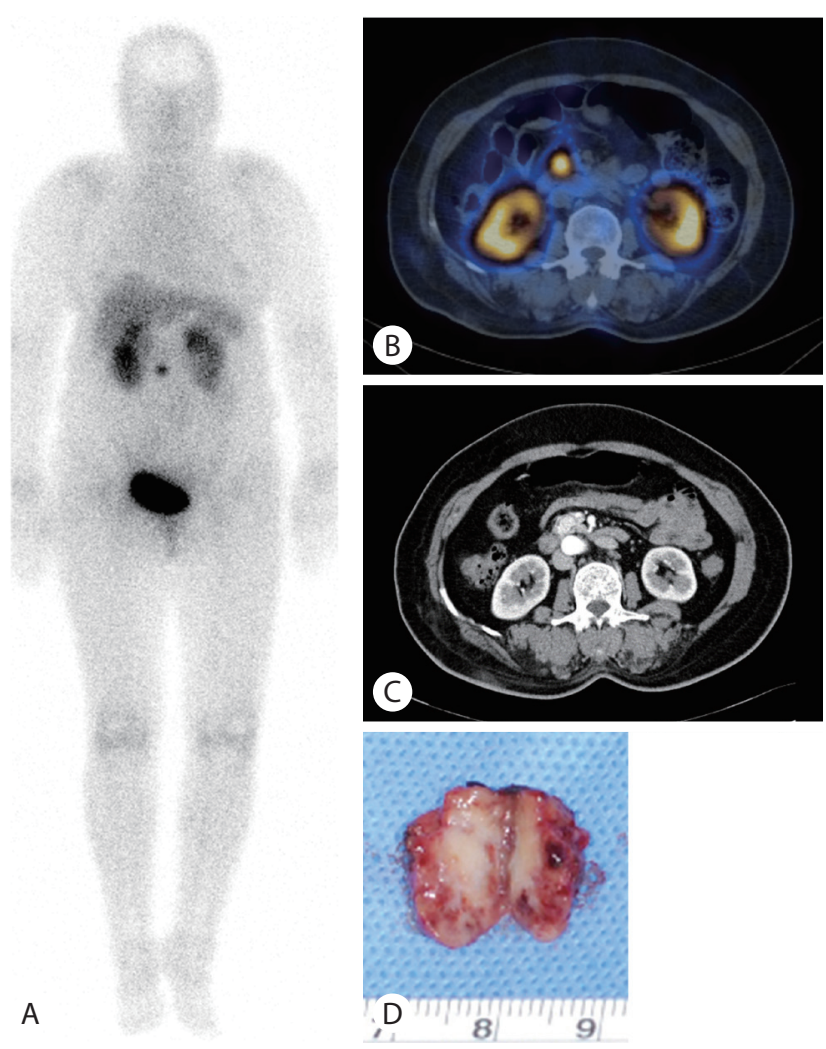

Fig. 1. Fifty-nine years old woman had suffered from recurrent seizures for three years. Her fasting serum glucose was $37 \mathrm{mg} / \mathrm{dL}$. (A) In-111 Octreoscan and (B) SPECT/CT showed hot uptake in the pancreatic head which is corresponding to the enhanced lesion on (C) CT. (A) Distant metastasis was not found on whole body scan. After resection of tumor, pathology revealed an insulinoma. SPECT, single photon emission computed tomography; $\mathrm{CT}$, computed tomography. 
279 개의 병변을 찾았으나 SPECT는 157 개의 병변을 찾았다. ${ }^{3}$ 이는 PET/CT가 SPECT에 비해 해상도가 좋기 때문이다. 소마토스타틴 유도체 $\mathrm{PET} / \mathrm{CT}$ 의 신경내분비종양 진단능 평가를 위해 Ga-68 표지 소마토스타틴 수용체 PET/CT 연구 21 개와 Cu-64 표지 소마토스타틴 수용체 PET/CT 연구 1개, 총 2,105 명의 환자를 대상으로 한 메타분석에 따르면 소마토스타틴 유도체 $\mathrm{PET} / \mathrm{CT}$ 의 신경내분비종양 진단 예민도는 93\% (95\% 신뢰구간 91-94\%), 특이도는 96\% (95\% 신뢰구간 95-98\%)로 평가되었다. ${ }^{4}$

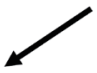 \\ G1, G2}

Pancreatic NET

- In-111 octreotide scan
and SPECT/CT
or
- Ga-68 DOTATOC PET/CT
or
- F-18 FDOPA PET/CT
and
- F-18 FDG PET/CT
if Ki-67 > 10\%

\section{- In-111 octreotide scan and SPECT/CT}

or

- Ga-68 DOTATOC PET/CT if $\mathrm{Ki}-67<50 \%$

and

- F-18 FDG PET/CT
Fig. 2. Diagnostic imaging algorithm for patients with pancreatic neuroendocrine tumor. NET, neuroendocrine tumor; SPECT, single photon emission computed tomography; $\mathrm{CT}$, computed tomography; $\mathrm{PET}$, positron emission tomography; FDOPA, fluoro-dihydroxyphenylalanine; FDG, fluorodeoxyglucose.
$\mathrm{G} 1, \mathrm{G} 2$ 와 같이 잘 분화된 신경내분비 종양에서는 F-18 fluorodeoxyglucose (FDG) PET 영상에서 섭취가 거의 없는데 비해, G3와 같이 분화도가 나쁜 경우 소마토스타틴 표적 기능 영상에서는 잘 보이지 않고 FDG PET에서 잘 보인다. 28명을 대상으로 한 연구에서 분화도가 좋아도 FDG 섭취가 높을 경우 무진행생존기간 및 총생존기간이 짧았다. ${ }^{5} \mathrm{G} 3$ 의 경우에도 분화도가 좋으면 소마토스타틴 표적 기능 영상에서는 잘 보이는 경우가 있다(Fig. 2).

Ga-68은 물리적 반감기가 68분인 양전자방출 핵종으로, 반감기가 271일인 $\mathrm{Ge}-89 / \mathrm{Ga}-68$ 발생기를 이용하여 생산이 가능하다. 따라서 F-18과 달리 사이클로트론이 없어도 PET 검사를 할 수 있으나 발생기 가격이 수천만 원에 이르러 일부 병원에서만 사용하고 있고 상업적 대량 생산이 어려워 Ga-68 DOTATOC을 구입할 수 없어 PET/CT가 있어도 검사를 못하는 병원이 많다.

소마토스타틴 수용체 기능 영상은 다음과 같은 목적으로 사용될 수 있다. ${ }^{6}$

- 작은 기능성 종양의 원발 병소 위치를 찾거나 선암과 감별 진단

• 병기 판정

•치료 후 효과 판정 및 재발 병소 진단

•옥트레오티드 치료에 적응이 될 환자 선별

-소마토스타틴 수용체 방사성핵종 치료 대상 환자 선별

신경내분비종양은 세포들의 아민 전구물질 섭취 및 탈카르복실화라는 대사과정과 밀접한 관련이 있기 때문에
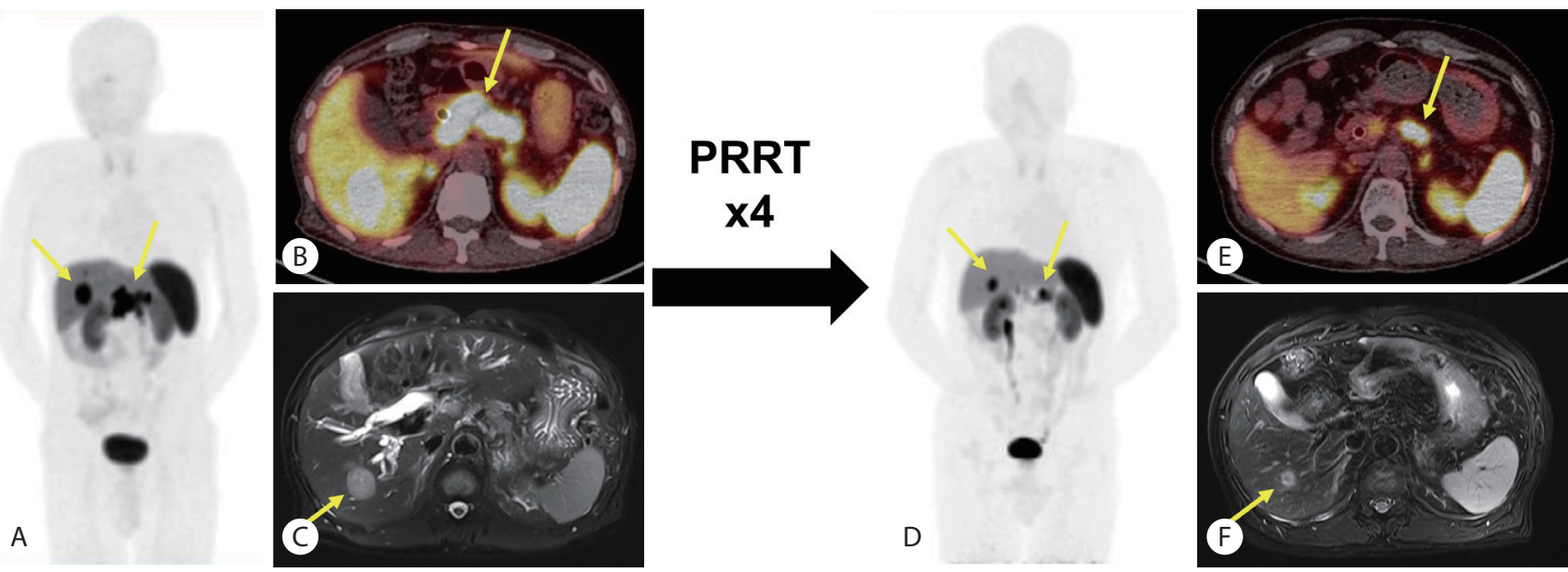

Fig. 3. A 66-year-old man with jaundice was diagnosed to have a pancreatic neuroendocrine tumor with liver metastasis (grade 2). He received 4 times of Lu-177 DOTATATE treatments (PRRT). (A, B) The size of tumors on Ga-68 DOTATOC PET/CT and (C) T2 weighted MRI prior to PRRT decreased after treatments on (D, E) Ga-68 DOTATOC PET/CT and (F) T2 weighted MRI. PRRT, peptide receptor radionuclide therapy; PET, positron emission tomography; $\mathrm{CT}$, computed tomography; MRI, magnetic resonance imaging. 
APUDoma라 불릴 정도로 아민 대사와 밀접한 연관을 가지고 있다. 아민 전구물질로 L-DOPA는 세포 내에서 도파민과 세로토닌으로 변환되며 세포질 내의 분비과립에 저장되고, 자극에 의해 세포 밖으로 배출된다. 이러한 성질을 이용하여 F-18 FDOPA가 신경내분비 종양의 PET 영상에 이용된다. F-18 FDOPA PET/CT는 65-85\%의 예민도로 Ga-68 DOTATOC PET/CT에 비해 낮으나 Ga-68이 없는 경우 대신할 수 있는 검사이다.

\section{2. 펩타이드 수용체 방사성핵종 치료(peptide receptor radionuclide therapy, PRRT)}

표적 영상진단에 사용되는 바이오마커는 같은 원리로 표적치료도 가능한데 베타선을 내는 방사성핵종을 표지한 Y-90 DOTATATE나 Lu-177 DOTATATE를 이용한 PRRT로 전이성 신경내분비종양을 치료할 수 있다(Fig. 3). Lu-177은 베타선과 감마선을 동시에 방출하여 고용량의 Lu-177 DOTATOC을 이용하면 치료뿐만 아니라 전신스캔 및 SPECT/CT를 촬영하여 섭취 정도를 모니터링을 할수 있다.

허가 받지 않은 의약품을 다른 치료 방법이 없는 경우 동정적 치료를 할 수 있는 독일, 호주 등에서는 신경내분비종양 치료로 PRRT를 20년 이상 사용하였으나 특허가 만료되고 희귀 질환이어서 어느 제약회사도 허가를 위한 임상시험을 하지 않았다. 프랑스의 AAA라는 제약회사가 이미 임상적 사용 경험이 많고 미국 Food and Drug Administration에서 희귀의약품으로 지정 받아 임상시험을 하고 품목허가를 받으면 7년간의 독점권을 받는 것에 착안하여 중간창자 신경내분비종양 환자를 대상으로 Lu-177 DOTATATE 치료에 대한 다기관 3상 임상시험인 NETTER-1을 수행하였다. 치료군 116 명의 환자에서 $7.4 \mathrm{GBq}$ 의 Lu-177 DOTATATE를 8주 간격으로 4회 투여하고 대조군 113 명의 환자에게는 $60 \mathrm{mg}$ 의 장반감기 옥트레오타이드를 4 주 간격으로 투여하여 비교한 결과 20 개월 추적 무진행 생존율이 치료군은 $65.2 \%$, 대조군은 $10.8 \%$ 로 유의하게 치료군이 높았다. ${ }^{7}$ 치료군의 G3-4 호중구 감소, 혈소판 감소, 림프구 감소는 각각 $1 \%, 2 \%, 9 \%$ 였으며 관찰 기간 중 신장독성은 나타나지 않았다. 이 임상시험의 결과를 근거로 Lu-177 DOTATATE (Lutathera)는 유럽, 미국에서 각각 2017년, 2018년 위장관췌장 신경내분비종양 환자를 치료할 수 있는 신약으로 등재되었다. ${ }^{8}$ 핵의학치료 신약의 상품가치를 인정받아 AAA사는 39억 달러에 노바티스로 인수되었다.
우리나라에서는 신경내분비종양 환자들이 해외원정 치료를 받아왔고 2019년 10월부터 한국희귀·필수의약품센터를 통해 개인이 구매하여 서울대학교병원, 서울아산병원 등 핵의학과에서 치료를 시작하였다. 저자와 신경내분비종양 환우회는 노바티스와 협의하여 식품의약품안전처에 신약허가를 위한 신청을 하였고 신속심사를 통해 2020년 7월 품목허가를 받았다. 한편 2010-2015년 한국원자력연구원은 과학기술부 연구과제를 지원받아 국산 Lu-177 DOTATATE를 개발하였다. 2018년부터 보건복지부 지원을 받아 치료불응성 및 진행성 신경내분비종양 환자에서 펩티드수용체 방사핵종치료의 비임상 및 임상 1 상 시험을 진행 중이다.

아직 확립이 되지 않은 이슈는 옥트레오티드, 에베로리무스, 수니티닙, 간동맥화학/방사선색전술 등 기존 치료와 어떤 순서 또는 어떤 병합치료를 하는 것이 더 효과적인지, PRRT 4회 치료 후에 다시 진행할 때 어떤 간격으로 몇 회나 추가 치료를 할 것인지 등이 있다. G3 신경내분비종양 중 분화도가 좋은 Ki-67 $<55 \%$ 이하의 환자를 대상으로 NETTER-2 다기관 3 상 임상시험이 진행 중이다.

$\mathrm{Lu}-177, \mathrm{Y}-90$ 등 베타선을 방출하거나 Ac-225, Bi-213 등 알파선을 방출하는 방사성동위원소를 표지한 펩티드수용체 치료는 고에너지 감마선을 방출하는 I-131과 달리 특별한 치료병실에서 입원할 필요가 없이 외래에서도 치료가 가능하여 핵의학치료를 활성화하는 데 유리한 조건이다. 특히 알파핵종 치료제의 경우 기존 베타핵종 Lu-177 DOTATATE 치료에 반응하지 않는 환자에서도 치료 효과가 뛰어나 핵의학 치료의 미래의 주역이 될 것이다. ${ }^{9}$

\section{결 론}

췌장신경내분비종양은 소마토스타틴 수용체의 발현이 증가되어 있어 이를 표적으로 하는 기능 영상과 펩타이드 수용체 방사성핵종 치료가 가능하다. 기능 영상에는 In-111 옥트레오타이드 스캔 및 SPECT/CT와 Ga-68 DOTATOC $\mathrm{PET} / \mathrm{CT}$ 가 우리나라에서 시행하고 있으며 방사성핵종 표적치료는 Lu-177 DOTATATE가 최근 식품의약품안전처에 허가를 받았다. 신경내분비종양 환자에서 기능 영상으로 방사성핵종 표적치료 대상을 선별하는 분자영상을 이용한 정밀치료가 가능하다. 


\section{요 약}

신경내분비종양은 소마토스타틴 수용체의 발현이 증가되어 있다. 소마토스타틴 수용체를 표적으로 하는 소마토스타틴 유사체 옥트레오티드는 오랫동안 신경내분비종양의 기능을 억제하는 치료제로 사용되어 왔다. 옥트레오티드에 핵의학 영상용 방사성동위원소 In-111을 표지하여 환자에 주사한 후 감마카메라로 전신을 촬영하는 기능적 핵의학 영상 또한 오래전부터 사용되었다. 최근에는 옥트레오티드 유사체에 양전자단층촬영(positron emission tomography, PET)용 방사성동위원소를 표지하여 PET/CT를 촬영하게 되었는데 기존 In-111 옥트레오스캔보다 더 선명한 영상을 얻을 수 있다. 나아가 옥트레오티드 유사체에 치료용 방사성핵종을 표지하여 주사하면 신경내분비종양의 전이된 병소를 찾아가서 방사선 치료를 하는 일명 방사선 미사일 치료가 개발되었다. 이는 펩타이드 수용체를 표적으로 하는 핵의학 치료의 일종으로 펩타이드 수용체 방사성핵종 치료(peptide receptor radionuclide therapy, PRRT)라고 한다. 같은 소마토스타틴 수용체 표적 펩타이드를 이용하여 치료 전 기능 영상을 얻어서 PRRT의 대상 환자를 선별할 수 있어 환자 개인맞춤 정밀치료가 가능하다. 또한 Lu-177과 같은 영상용 감마선과 치료용 베타선을 동시에 방출하는 방사성동위원소를 표지하면 치료와 동시에 감마카메라 영상을 얻을 수 있어 주사한 표적치료제의 분포를 매 치료마다 평가할 수 있어 진단과 치료의 합성어인 테라노스틱스가 가능하다.

국문 색인: 방사선 치료, 신경내분비종양, 정밀의료, 소마토 스타틴 수용체, 핵의학영상

\section{Conflicts of Interest}

The author has no conflicts to disclose.

\section{Acknowledgments}

This work was supported by the framework of international cooperation program managed by National Research Foundation of Korea (NRF-2017K2A9A2A10013554 \& NRF-2020R1A2C2006767 to K.W.K).

\section{REFERENCES}

1. Shi W, Johnston $C F$, Buchanan $K D$, et al. Localization of neuroendocrine tumours with [111In] DTPA-octreotide scintigraphy (Octreoscan): a comparative study with CT and MR imaging. QJM 1998;91:295-301.

2. Wong KK, Cahill JM, Frey KA, Avram AM. Incremental value of 111-in pentetreotide SPECT/CT fusion imaging of neuroendocrine tumors. Acad Radiol 2010;17:291-297.

3. Buchmann I, Henze M, Engelbrecht $S$, et al. Comparison of ${ }^{68} \mathrm{Ga}$ DOTATOC PET and ${ }^{111}$ In-DTPAOC (Octreoscan) SPECT in patients with neuroendocrine tumours. Eur J Nucl Med Mol Imaging 2007;34:16171626.

4. Geijer $H$, Breimer LH. Somatostatin receptor PET/CT in neuroendocrine tumours: update on systematic review and meta-analysis. Eur J Nucl Med Mol Imaging 2013;40:1770-1780.

5. Hicks RJ. Use of molecular targeted agents for the diagnosis, staging and therapy of neuroendocrine malignancy. Cancer Imaging 2010;10 Spec no A:S83-S91.

6. Bozkurt MF, Virgolini I, Balogova S, et al. Guideline for PET/CT imaging of neuroendocrine neoplasms with ${ }^{68} \mathrm{Ga}$-DOTA-conjugated somatostatin receptor targeting peptides and 18F-DOPA. Eur J Nucl Med Mol Imaging 2017;44:1588-1601.

7. Strosberg J, El-Haddad G, Wolin E, et al. Phase 3 trial of ${ }^{177}$ Lu-DOTATATE for midgut neuroendocrine tumors. N Engl J Med 2017;376:125-135.

8. Hennrich U, Kopka K. Lutathera ${ }^{\circledR}$ : the first FDA- and EMA-approved radiopharmaceutical for peptide receptor radionuclide therapy. Pharmaceuticals (Basel) 2019;12:114.

9. Ballal S, Yadav MP, Bal C, Sahoo RK, Tripathi M. Broadening horizons with ${ }^{225}$ Ac-DOTATATE targeted alpha therapy for gastroenteropancreatic neuroendocrine tumour patients stable or refractory to ${ }^{177} \mathrm{Lu}$ DOTATATE PRRT: first clinical experience on the efficacy and safety. Eur J Nucl Med Mol Imaging 2020;47:934-946. 